\title{
ERRATA EM: Revista Brasileira de Educação Médica, volume 36, número 1, Janeiro-Março 2012.
}

ERRATUM IN: Brazilian Journal of Medical Education, volume 36, issue 1, JanuaryMarch 2012.

Erro na grafia do autor do artigo: "Terminologia da Atenção Primária à Saúde", Rodrigo Díaz Olmos. Revista Brasileira de Educação Médica. 2012; 36(1):93-9. 